\title{
THE TEMPORALITIES OF POLICY TRANSLATION IN THE SEMI-PERIPHERY: REVISITING THE EUROPEANISATION OF WELFARE REFORMS IN CENTRAL AND SOUTH EAST EUROPE ${ }^{3}$
}

\begin{abstract}
This article seeks to conceptualise time and temporality in the context of semi-peripheral social relations, with a particular focus on the transnational dimensions of policy translation. In particular, we show how, albeit within the co-existence of multiple temporalities, 'policy time' and 'time in policy' tends to enable and privilege particular kinds of policy processes over others. Revisiting a number of themes from our ethnographic work on social policy reform drawn, mainly, from the post-Yugoslav and Hungarian context and relating, mainly, to so-called 'Europeanisation' processes, allows us to foreground the spatio-temporal dimensions of policy processes. The text explores some key challenges in terms of how to treat time within critical policy studies.
\end{abstract}

Keywords: Temporalities, policy translation, critical policy studies, semi-periphery, Europeanisation

\section{Introduction: Notes on a Collaboration}

In our work, separately and together, we have exhibited a complex and ambivalent relationship to the three key concepts of this paper: translation, semiperiphery and temporality. In our joint writings on policy translation over many years, we have rarely made the concept of 'temporality' central to our work (although cf. Stubbs, 2018: 2020) even though a concern with 'time', most often in the combination concept 'temporal-spatial', has been present. The concept of 'semi-periphery' has a rather uneven history in our work: Stubbs' chapter in Making Policy Move (Stubbs, 2015a) relies, largely uncritically, on Blagojević's use of the concept (Blagojević,

\footnotetext{
${ }^{1}$ noemi.lendvai@bristol.ac.uk

${ }^{2}$ pstubbs@eizg.hr

${ }^{3}$ An earlier version of this paper was presented at a workshop Translating Policy in the Semi-Periphery, held at GSOSES, Regensberg, Germany. Particular thanks go to Čarna Brković for her encouragement during and after this event.
} 
2009) as a lens through which to understand the performativities of reform in South East Europe; our polemical text on 'Social Europe' in crisis (Stubbs and Lendvai, 2016), mainly focused on the EU's disciplining of the Western Balkans, hints at the coloniality of 'Eastern enlargement' as a reworking of 'core-periphery' relations but does not invoke 'semi-periphery' directly; and our post-comparative understandings of 'layered' welfare within the authoritarian austerity capitalisms of Croatia and Hungary (Lendvai and Stubbs, 2015) is far more reliant on a new critical geography than on anthropological or sociological formulations.

Much of our work, over more than a decade, has emphasised the importance of understanding policy through the lens of 'translation', albeit utilising a changing mix of theoretical influences across different texts (Lendvai and Stubbs 2007, 2009; Lendvai and Bainton, 2013; Stubbs, 2015b). Of course, our search, together with Dave Bainton and John Clarke, for "a vocabulary for policy studies" has always been conceived as 'provisional' and 'adaptive', seeking to convey, sometimes explicitly, "the process of intellectual enquiry that is involved in 'making up' an approach to policy studies" (Clarke et al., 2015: 35), so that we make no apologies for these inconsistencies.

There are a number of more consistent and common threads throughout this body of work, however. Three seem pertinent here. The first is a deep distrust of, dissatisfaction with and lack of interest in much of what passes for orthodox 'social policy studies', marked by a pseudo-objectivist "perspective from above or from "nowhere" (Marcus, 1995: 112), obsessed with regime typologies and adhering to a search for 'path dependencies'. It is not only that key concepts from the social sciences, indeed key social scientists, are missing from the scene or arrive late, and in highly simplified form, in the discipline (Clarke, 2004: 3). It is also that the boundary work of what is to count as 'social policy', focusing on particular taken-forgranted 'sectors', misses so much regarding shifting, pluriversal, non-Eurocentric, understandings of 'the social' and its complex articulations with other shifting domains of 'the economic', 'the political' and 'the ecological'. We have taken refuge in a broad 'anthropology of policy' approach (cf. Shore and Wright (eds.), 1997), based on a kind of 'ethnographic sensibility', akin to what Gould (2004) has termed 'hunting and gathering' or which we have termed the 'bending and blending' of our various positions and roles to gain insights into 'policy' as a constant translation between that which is defined as 'formal' and that considered 'informal' (Lendvai and Stubbs, 2007).

The second is our commitment to resist the temptation to explain away "policies with reference to any catch-all meta-term" (Jansen, 2017: 3), a tendency all too common in some Marxist or Foucauldian approaches. This tends, all too rapidly, to "move away from policy", to 'read off' "larger forces, tendencies or dynamics" be these 'neoliberal governmentality', 'the interests of capital' (Clarke et al., 2015: 34) or the like. We agree entirely that it is "bad social science to ignore (these) as a point of principle" (Jansen, 2017: 3). Our struggle is with how to trace the connections between different levels and scales without assuming them or making leaps which are not based on sound social scientific reasoning. Above all, this involves a 
commitment to taking seriously, if not actually appreciating, the contradictions of the everyday practices of what one anthropologist described as 'national scale state actors'4. Combining a kind of 'studying up' and 'studying through' (Wedel, 2004) with a methodological imperative of needing to 'follow the policies' as they are "iteratively remade through their imperfect actualization across multiple sites" (Peck and Theodore, 2015: 27) still faces the problem of the many 'policy elsewheres' (Stubbs, 2015a; 92) which remain hidden and/or out of reach. However, attempting to demonstrate the linkages, disconnections and contestations, along an axis 'policy maker' - 'front-line worker' - 'service user', attuned to the rise of intermediary-type hybrid 'flex actors' (Stubbs and Wedel, 2015), seems preferable to over-ambitious meta-claims.

The third, very much learned from collaborations with John Clarke, is the importance of connecting 'conjunctural time' with 'micro-political time', sensitive to 'emblematic moments' (Jessop, n.d.) but wary of 'epochal time'. Some kinds of Marxism, along with other totalising systems theories, are prone to foreground the 'epochal' as the prime, if not sole, determinant of social action, as "the only relevant temporal form that helps determine the operation and identity of agency in the international system" (Xin Liu, 2012: 3). 'Micro-political time', akin to Ruggie's concept of 'incremental time' which "slices social time into a succession of discrete and infinitely divisible units" (Ruggie, 1998; 157) is closer to an anthropological understanding of 'everyday life'. Sharing Raymond Williams' (1977) distrust of the abstractionism of 'epochal analysis', in favour of attention to "the internal dynamic relations of specific moments" (Clarke, 2010: 340), Clarke suggests the need to replace a "fixation on the dominant" (ibid) with a focus on the hegemonic work needed to "contain, displace, neutralize or incorporate" (ibid) elements of what Williams terms 'the emergent' and 'the residual'. For us, conjunctures are momentary 'spatio-temporal fixes' (Jessop, 2004), bounded states of forces and flows, sometimes coming together as 'perverse confluences' (Dagnino, 2007) combining different, even seemingly antagonistic, discursive formations. 'Emblematic moments', both 'momentary' and 'momentous', akin to 'incidents' or 'dramatic effects' (Gordy, 2013: xii), are segments of social time which lead or are likely to lead to "an eminent turnabout in the development of social relations and forces" (Martinelli and Novy, n.d.). Micro-political moments are more like 'the everyday', may be more or less 'routine', but can be improvised, performative, encounters in 'contact zones', marked by "the spatial and temporal copresence of subjects previously separated by geographic and historical disjunctures, and whose trajectories now intersect" based on "radically asymmetrical relations of power" (Pratt, 1992: 6-7).

In setting out these consistencies, particularly the third, we already run into what we might term 'trouble with time'. For how can 'time' be both the subject and object of discussion; be both a given constant and a variable? Indeed, revisiting 'contact zones', just as the spatial is more than merely geography, we argue that the temporal is much more than history and, certainly, very different from linear notions of past,

\footnotetext{
${ }^{4}$ Andre Thiemann, email correspondence, 7 February 2017.
} 
present and future. Foregrounding time and temporality are, therefore, long overdue in our work and the way in which 'time' is translated, in the sense of "processes of complex becoming, modification, distortion and transformation" (Stubbs and Lendvai, 2016: 34), in semi-peripheral reform contexts presents an ideal opportunity to do so. The next section seeks to conceptualise time and temporality in the context of semi-peripheral social relations. This is followed by revisiting a number of themes from our ethnographic work on reform drawn, mainly, from the post-Yugoslav and Hungarian context and relating, mainly, to so-called 'Europeanisation' processes. A tentative final section draws conclusions and raises dilemmas about how to treat time within critical policy studies going forward.

\section{Time in the Semi-Periphery}

Time and temporality are rather Janus-faced within the literatures on 'transitology', 'Europeanisation', social policy and policy studies. Whilst it is recognised that time is hugely important in understanding welfare reforms, postcommunist transformation, processes of Europeanisation and the transnationalisation of social policy with multiple actors operating across multiple scales, it tends to be largely taken for granted, or trapped in binary or modernist linear logics. Instead of a complex dialectic, challenging notions of 'stability' and 'change', studies either emphasise 'path dependency' and 'legacy effects' or promote a kind of free-floating understanding of policy change over time. In the process, we are offered a frozen temporality, through reifying the past, as in the case of path dependency, or reifying the future, through an obsessive focus on change. For us, occupying a variety of roles such as 'researchers', 'consultants', 'activists', or 'policy advisers', it has long been evident that such constructs are unproductive. Everyday practice in complex settings results in a kind of juxtaposing of tenses; memory does not only belong to the past, and the imagined and performed 'new' is not that of the present and future only. Our focus, discussed empirically below, suggests that the co-production of tenses implies that memory and amnesia are both performed in 'reform initiatives'. As such, understanding the co-production of multiple tenses is a more relevant starting point than a search for 'dependent' and 'independent' variables and 'causal' relationships. As we argued in Making Policy Move: "the recombination of time and space, as in the timetables or timelines of policy implementation, is neither natural nor technical, but deeply social, political and contestable" (Clarke et al., 2015: 21). Bakhtin's (1981) notion of 'chronotopes', originally applied to fiction, as adapted by Gilbert (2019), despite being "notoriously difficult to pin down" (Jansen et al., 2016: 21 ), suggests both the inseparability of space and time and the work which such literary devices perform in developing communicable images of 'when' and 'where' without which the 'how' becomes an empty signifier. This is not, at all, the same as 'chronopolitics' noted above.

In mainstream accounts of welfare development in Central and South Eastern Europe the complexity of the temporal dimension, in terms of the 'work' which 
constructions of 'time' perform, has been largely lost. Instead of understanding temporality as causality, we should define time "in relation to the purposes it serves. Hence, we can never say what time is. Instead, we can only ask what kinds of worlds different forms of time make possible, and what interests are served by the creation of such worlds" (Allen, 2008: 217). The Janus face of time is precisely this; whilst it is taken-for-granted, tacit and salient, it is deeply productive: time selects, makes, crafts and enables different kinds of worlds to be made and remade. Welfare reforms are a form of 'time telling', categorizing 'pasts, presents and futures', utilizing tropes of 'progress' and 'modernisation' and, in the process, allocating different sections of the population to different positionalities, such as 'old-fashioned', 'nostalgic', 'forward-looking', or 'visionary' (Clarke et al., 2015: 29).

Like spatiality, then, temporality is crucial for the production, reproduction and translation of policy worlds. It is rarely encountered in the singular, however, and rarely acts alone. In this sense, the notion of 'heterotemporalities' is important in capturing "the infinitely varied experiences of time that can coexist and interact simultaneously at multiple locations and scales operating within and against dominant chronopolitical tendencies" (Huebener et al., 2016: 246). For Huebener et al. (2016) 'chronopolitics' denotes a kind of temporal-spatial power in the context of globalization, including "the conceptions and practices associated with colonialism" which challenges "the assumption that time is a background experience that is independent of human agency" (ibid: 246).

The concept of heterotemporalities alerts us to the sense that time is always multiple, operating at different speeds and across different scales and sites. In complex policy worlds, it is not just that different actors invoke different notions of time or operate according to different time-scales; rather the same actor can invoke multiple notions of 'time' and operate at different speeds in different contexts. The World Bank, Ministries of Social Affairs, local authorities, Social Work Centres, the European Commission, domestic policy makers, local and international consultants, politicians, and welfare users, each act according to complex heterotemporalities, in multiple relations of power, domination and resistance. Welfare reforms are produced, reproduced and translated within multiple heterotemporalities. This is not to rule out the existence of, nor the working towards, a kind of 'hegemonic temporality' that 'temporarily and not 'naturally' of course, prevails over others despite not managing to ... assimilate them completely" (Filippini, 2016: 106). Rereading 'time' in the work of Gramsci, Filippini goes on to suggest, crucially, that "this force not only endeavours to get time to conform to it, as a specific mode of its own prevalence over other temporalities, but at least in part it also over-determines the rules of the struggle" (ibid.), not least through the setting of policy timetables and, crucially, deadlines.

In the current conjuncture, marked by globalisation and transnationalisation, it may be that 'fast time' and 'fast policies' constitute an emblematic form of hegemonic temporality. Nevertheless, there is a danger of over-stating the importance of the speed of policy production, reproduction, transfer and translation, isolating it from other features of contemporary policy developments and, above all, over-emphasizing its 
novelty. Peck and Theodore's book Fast Policies (Peck and Theodore, 2015) might, on casual reading, seem to be suggesting precisely this, although a closer reading suggests a more nuanced argument. An earlier text by Peck leads in this direction, emphasizing how "contemporary policy making processes seem to be accelerating" referring to 'shortened policy development cycles', 'intensity of cross-jurisdictional exchanges', 'compressed reform horizons', and 'prescriptively coded front-loaded advice and evaluation science', such that "policy ideas and techniques have become mobile in entirely new ways" (Peck, 2011: 773-4). The 'fast' pace of global or transnational policy is then contrasted with the 'slow' pace of change on the ground and, in particular, with 'slow national time' (Sassen, 2018). Again, this distinction between 'fast' and 'slow' is too linear and binary and may fail to capture the range of heterotemporalities in play as well as the work they perform. A contrast between 'national' and 'global' time, reproduces false dichotomies of the spatial, also. Confining 'fast' and 'slow' to specific spatial scales in this way is neither analytically useful nor empirically verifiable. Crucially, it is the multiple temporalities, and multiple spatialities, of different actors that make different policies possible. Whilst it may be the case that 'fast policies' are enabled by, and operate through, a variety of technologies (ready-made templates, pre-set formulas, decontextualized policy frameworks and the like) that may be externally produced, these always need to become internally anchored, in the process of which they are translated and change. It is precisely this double movement of transformation/translation and locatedness/ anchoring that demands much more attention to the temporal as well as the spatial dimension.

A careful reading of Peck and Theodore suggests that speed as measured by how much time has elapsed is not the main issue. They also, rightly in our view, suggest that searching for a single origin of a 'fast policy' and tracing its linear movement across space and time is misplaced, referring instead to "dense networks of relations, and multiple modes of translation and reinvention" (Peck and Theodore, 2015: 78). 'Following the policy' must not be at the expense of exploring social relations in situ, including shifting, sometimes unexpected, relations between the 'political' and 'technical', the unfinished quality of 'models' and 'technical fixes', and complexities of heterotemporalities going far beyond the co-existence of 'the fast' and 'the slow'. The temporalities of policy, then, are complex and multiple, marked by diverse "temporal rhythms and ruptures" (Coffey, 2004: 103) and, often, 'competing hegemonic times' as well as a competition between states and statelike actors to "hegemonically (but also coercively) unify their respective societies" (Filippini, 2016: 113).

In some ways, a static understanding of the 'semi-periphery', derived from world systems theory, reified as a space between 'the core' and 'the periphery', exhibiting "cultural and social institutional features intermediate in form" (Domazet and Marinović Jerolimov, 2014: 24), can lead to ill-conceived understandings of 'transition' and 'transformation' based on a kind of 'temporal slope' theory (Fabian, 1983: 17). This becomes marked by an inevitable sense of 'evolutionary time' in which modernization and development is meant to result in 'catch up' or 'convergence', 
whether this occurs rapidly or slowly. Marina Blagojević's more anthropological take on the concept, emphasizes the paradoxes and contradictions of policies meant to 'speed up' modernization in conditions of deindustrialisation and retraditionalisation, including desecularization, repatriarchisation and anti-intellectualism (Županov, 2002). Elites tend to make 'formal adjustments' to reform priorities imposed from outside, which are then judged by those same external actors as both too little and too slow, a clear example of the double movement discussed above. She suggests both the co-existence of "simultaneous opposition and acceptance, imitation and rejection" (Blagojević, 2009: 99), marked by the establishment of a kind of 'open space' for all manner of experimentations and policy innovations, "while at the same time lack of "structureness' severely limits the scope of their effectiveness" (Blagojević, 2009: 72) and institutionalization. Although helpful in some ways, this can also reinforce a crude binary between external 'speed' and internal 'inertia', ruling out other possibilities. It remains to be demonstrated empirically whether the semi-periphery is marked by a different set of heterotemporalities than either the socalled 'developed' or 'developing' worlds, but these are primarily 'conjunctural' and 'micropolitical' questions, not epochal ones.

Certain features of post-socialist (and post-conflict) change may lend themselves to a kind of 'queer asynchrony' or 'temporal disjunction' (Mizielinska and Kulpa, 2011) in which long-term historical translations become bundled together in 'new' contexts, in new 'heres and nows', becoming very different assemblages in the process. They are best addressed through a kind of 'cross-contamination' of 'post-colonial' and 'postcommunist' studies which was what we were aiming for in our chapters in Making Policy Move. However, ushering in yet more radical dichotomies comparing Western 'times of sequence' and Eastern 'times of coincidence' (Mizielinska and Kulpa, 2011: 15) may obscure as much, if not more, than they reveal, setting up new binary oppositions, 'othering' the so-called 'East' and asserting that which needs to be verified empirically. 'Queer time', contrasted to core 'straight time', directs us, perhaps, to “turn away from narrative coherence", and provides "insights about embodiment, counterhegemonic practices" and subjugated, disqualified and anticanonical knowledges and practices (Halberstam, 2005: 182). If 'semi-peripherality' can be understood in this way, it may be a useful lens; if not, then it reproduces Western normativities even in the act of attempting to deconstruct them.

Our concern with heterotemporalities and hegemonic time as both imposed and resisted leads us back to studying processes of EU integration, EU enlargement (Goetz, 2006; Avery, 2009) and Europeanisation as chronopolitical projects marked by complex heterotemporalities. The radical compression of policy time is well captured in concepts such as the 'tsunami neoliberalism' of 'shock therapy' (Klein, 2007), or in Janine Wedel's use of a cartoon from transition Poland in which a male Western consultant is phoning home and states: "I am here to privatize the economy, I'll be back by Friday" (Wedel, 2001). At the same time, Arsenijević and Wastell (2017) argue poignantly that we are witnessing an 'enduring transition', namely "a transition that does not query where history is/should be going, and as a result, a transition without any seeming end" (Arsenijević and Wastell, 2017). 
The chronopolitics of EUAccession, or as Stoker(2006)terms itEU assimilation, assumed a tight timeframe for 'compliance'. More and more literature unpacks the nature of this managed and compressed time and its long-term consequences for New Member States and prospective Member States (Sissenich, 2007; Stubbs and Lendvai, 2016; Lendvai-Bainton, 2017). As such heterotemporalities, whilst multiple, are also deeply structured by power and inequalities. Temporality fundamentally structures key issues such as 'policy learning', 'opposition' and 'resistance', 'implementation', and 'epistemic communities'. Temporalities are also performed, shaping and being shaped in practice. Welfare reforms, the adoption of legislative frameworks and the social acquis are performed, often with social 'projects' being delivered as 'fictions'. Performativity is deeply temporal as well as political, as it speaks to the impossibility and multiplicity of time. In the next section we revisit four key themes in our work on welfare reforms in Hungary and the post-Yugoslav space through the lens of temporality. In turn, these are: Learning and Unlearning; Policy Fictions; Flexible Agencification; and Projectization. In the process, we rather flatten the temporality of our work, drawing on issues and themes derived from a long period of time without, here, referencing the conjunctural conditions. As such, this should be seen as merely a tentative first step in the recovery of temporality in our work.

\section{The Heterotemporalities of Social Europe: Revisiting Reform Encounters}

\section{Learning and Unlearning}

Although the idea of 'policy learning' has a central place in the European Union's 'Open Method of Co-ordination' for social policies, as a mechanism of 'soft governance' (Buchs, 2008), it is present, implicitly or explicitly, in the practices of other international actors active in influencing reform agendas in Central, Eastern and South Eastern Europe. As an 'innovative', 'deliberative' and 'experimental' method (cf. Zeitlin, 2005; de la Porte, 2011) it has become the privileged means of promoting the so-called 'diffusion' of so-called EU 'norms', communicating a common set of definitions and, above all, inducing institutional adaptation and change. Clearly, both the nature of the process and the contents of the learning differ between 'new' (e.g., Hungary, still so labelled despite joining the EU in 2004), 'newer' (Croatia), and 'aspiring' Member States. However they are understood, the temporalities of conceptual, cognitive, normative and institutional change are, clearly, rather different: "of course, real change in practice on the ground takes time" is frequently invoked by policy makers and scholars of policy, active in and around the technologies of policy learning such as 'peer reviews', 'learning from best practice', and 'benchmarking' exercises, without challenging the 'logics of modernity' (Lendvai, 2007) being implied.

Conceiving of 'policy learning' as a 'zone of translation' (Lendvai, 2015) suggests that what is being learnt may be very different in the fluid, uneven, and 
unstable institutional landscapes typical of the 'semi-periphery'. New actors, more skilled in EU-speak and/or the language of international development, occupy new positions as key intermediaries, forging ahead with the reconfiguration and supposed modernisation of policies, advocating 'holistic' and 'joined up' government in the face of so-called 'traditional', read 'backward-looking', civil servants (cf. Lendvai and Stubbs, 2009). At the same time, they often sympathise with domestic actors, critiquing the lack of 'understanding' of local realities on the side of international actors. Their power rests, therefore, precisely on their ability to "translate the (universal) values of modernity into locally or nationally implementable schemes" (Stubbs, 2013: 136). The heterotemporalities of new hybrid translators is apparent, invoking different speeds and timetables and time horizons with different actors.

The rapidity of 'policy learning' exercises actively mitigates against true lesson learning and lesson drawing, of course. Crucially, in place of 'mutual learning', a more or less taken for granted 'line of best fit', based on an 'illusion of similarity' (Lendvai, 2015) is imposed, with multiple potential lines of influence shut down and semi-peripheral spaces reconstructed as tabulae rasae or as having 'legacies' which are best 'unlearned'. A political act of 'double subordination' occurs, attempting to erase knowledge of social policy in the 'semi-periphery' whilst simultaneously subordinating social policy to economic growth, competitiveness, debt and, in the case of 'aspirant' Member States to consolidation of democracy, the rule of law and 'respect for human rights'.

The 'study trip' represents the crudest form of instrumentalised temporality of 'learning' in 'core' - 'semi-periphery' relations. Indeed, recently, one of us was told by a consultant working on an EU-funded 'twinning' project, bringing together two or more cities to engage in 'knowledge and practice exchanges', that the 'secret' of winning such contracts is: "if you know your competitor is proposing four study trips, then you propose five". Often associated with opportunities for material consumerism rather than 'policy shopping', the latter can still occur: Zagreb's Mayor Milan Bandić is widely reported to have conceived of putting a large number of municipal services into a single holding company, an ideal vehicle for cementing local state capture and clientelistic practices, following USAID funded study visits to Vienna and Graz (Hoffman et al., 2017).

As one of us has tried to suggest (Clarke et al., 2015: 212 - 214), embracing a translation lens could lead to 'learning otherwise', not to be confused with the radical form of 'unlearning', akin to destruction or forgetting of all that has gone before, advocated by, for example, the World Bank, in welcoming the fact that war allowed for social policy to 'start afresh' in Bosnia-Herzegovina (Stubbs, 2001). Rather this would be a more counter-hegemonic, politicised dialogue, with subaltern actors 'talking back', learning from 'policy elsewheres' in, inter alia, Latin America or Africa, learning from silenced voices, and working with the multiple, choosing explicitly temporal and spatial disjunction over hegemonic domination. The lack of 'learning otherwise', particularly in the context of lack of reference to Latin America and Africa, when understanding welfare reforms in Eastern Europe is highly indicative of how 'learning' is produced in transnational policy circuits. The 
EU's Open Method of Coordination, a policy tool designed to promote and foster 'policy learning', assuming seemingly formal and equal participation by all Member States, has been deeply unequal in terms of what is supposed to be 'learned'. In one of our fieldwork sites, policy makers working in the Ministry for Social Affairs continued to complain that OMC workshops and peer reviews failed to listen to the fact that the Hungarian partner wished to include housing in discussions of social inclusion. As one of the key Hungarian representatives argued: "for 4 years they (Old Member State representatives) kept saying that housing is not part of social inclusion, in the fifth year it appeared as a priority. It was very tiring having to have to insist on such a fundamental point". Reconfiguring an Open Method of Coordination (OMC) as a more dialogic and democratic method is only possible if policy agents pay attention to the conjunctural and recognise heterotemporalities in translation, we would suggest.

In the context of EU membership and integration, what is being learned and how learning is assumed, produced, and imposed, often under 'time pressures', is deeply political. The OMC, for example, has long been assumed to promote learning of 'activation', 'gender mainstreaming' and 'social dialogue', blending Scandinavian, German, Dutch and Danish-style policies. However, when one turns to look at recent welfare changes in a number of Eastern European member states including Hungary, Poland, Slovakia and Croatia, the content of these OMC policy repertoires has been translated, often through rejection, reversal or even elimination from domestic policy discourses and practices. In Hungary, 'activation' has been translated into the deep disciplinarity of 'forced public work programmes' for 'undeserving groups' (Bako, et. al, 2014, Szikra, 2014). Gender mainstreaming has been banned as a term and, in its place, deeply paternalistic family mainstreaming initiatives have emerged (Juhasz, 2012; Lendvai-Bainton, 2017, Stubbs and Lendvai-Bainton, 2020). The $\mathrm{OMC}$ assumes a deeply apolitical character to policy learning, at a time when a reactionary and authoritarian backlash in many Member States has problematised the 'unity' of supposed 'core European values'. Ironically the insistence of the EU on 'unity' and 'core' in 'Europe' serves to undermine and pre-empt 'learning otherwise'.

\section{Policy Fictions}

The enactment or performance of 'policy fictions' is central to European integration as a set of non-linear, neo-colonial, processes and encounters (Stubbs and Lendvai, 2016: 32). 'Policy fictions' are unstable discursive assemblages that, although apparently "intangible and weightless" (Lendvai, 2015: 145), are always embedded in material relations and frame the ways policies are "understood, enacted, enforced, resisted or colonised" (Lendvai, 2015: 150). Fictions, as literary narratives, inevitably contain 'chronotopes', or sets of temporal and spatial understandings and relationships, fused together as a whole, usually within a logic of 'modernisation'. Indeed, it is the narrative dimension of both 'chronotopes' and 'policy fictions' that we find most compelling. The most recent iteration of this within 'social Europe', the Commission's 'European Pillar of Social Rights' initiative, states that it is "presented 
with today's and tomorrow's realities in mind" (European Commission, 2017: 3). The document boasts that the EU is "home to the most advanced welfare systems in the world and to a wealth of best practices and social innovations" but that "it needs to confront and adapt to unprecedented social challenges" (ibid: 3). At the same time, the applicability of the Pillar is reserved for "Member States of the euro area" together with any other Member States "that wish to be a part of it" (ibid: 5). The Pillar provides the latest major chronotope of social Europe following the Lisbon agenda, Europe 2020 and others, and contains its own minor chronotopes in the form of social scorecards to go alongside the emphasis within EU accession and membership on strategies, indicators and objectives all of which are supposed to require clear and consistent 'timelines'.

Amongst policy makers, EU accession allows for a particularly perverse kind of 'policy learning' which is that fulfilling the fictions of social Europe is less important than the austerity-driven and debt-reduction requirements of the European Semester, dividing the year, much like in higher education, into two segments, within a radical "recalibration of regulation" (Stubbs and Lendvai, 2016: 38) in the EU since the economic and financial crisis. In aspiring to EU membership, a World Bank-led fiction of 'poverty reduction' strategies was replaced by more European sounding 'social inclusion' strategies even if the concept was difficult to translate (becoming 'social togetherness' in Hungarian and inducing fierce debates in Croatia as to whether the term should be active or passive, referring to an outcome or a process). During Croatia's accession to the EU, the Joint Memorandum on Social Inclusion (known as JIM), alongside the Joint Assessment of Employment Processes (JAP), formed the key mechanisms for the European Commission to influence Croatia's social and employment policies (cf. Stubbs and Zrinščak, 2013). Each document required Commission approval and was subject to annual monitoring and feedback. At a joint JIM-JAP conference in 2010, alongside "enhancing the social inclusion of vulnerable groups" and crisis proofing some social spending, the emphasis was, very much, on including "all relevant stakeholders and social partners" as well as, in a clear example of EU-speak, changing "the disproportion of the labour force skills on the labour market" (Government of Croatia, 2010). The JIM process, in particular, was marked by complex heterotemporalities, with rapid actions before high profile conferences interrupting slower temporal rhythms. Currently, candidate countries including Montenegro, Serbia and North Macedonia are preparing 'Employment and Social Reform Programmes' that, more explicitly, link social policy, labour market and macro-economic concerns. Commission officials argue, not unlike the case of Croatia, that the long timeline before likely membership allows for major 'technical' advances to be made in social policy 'under the radar'.

In the JIM monitoring process, Croatian government civil servants learned that reporting annual progress through merely cutting and pasting from previous years would not pass and began to understand the importance of fictional portrayals of progress at least having a degree of narrative novelty compared to the previous year. In Hungary the fiction of the $\mathrm{OMC}$ in relation to social inclusion and social protection has long been mastered, with copying and pasting from previous reports 
combined with the presentation of incomprehensible text on 'strategic and longterm visions on social welfare'. The fiction of EU integration is an extensive list of activities in Hungary: setting and failing debt targets, faking implementation reports on Structural Fund projects, redefining key concepts and allowing funding for political activities linked to the new authoritarianism as, for example, the funding of an anti-abortion campaign in Hungary by the EU Progress Fund under the heading of gender mainstreaming (Juhasz, 2012). Fictions arise both as a response to the practical impossibilities of imposed time for implementation, 'saving time', as well as a form of political defiance and mockery against the 'core' and 'European unity', precisely reworking in a reactionary way the contradictions of the deeply colonial roots of EU integration (Stubbs and Lendvai-Bainton, 2020). The proactive use of strategies such as the 'copying and pasting' of policy texts, the production of incomprehensible texts and the fictional narratives of progress all work here towards deconstructing both the political framing and values of 'European social policy' as well as the technical elements of policy compliance. In the case of Hungary, this is not an 'implementation gap' or 'unintended consequence'; it is a deliberate political strategy.

The heterotemporalities of policy fictions are multiplied when, alongside such 'strategic documents', a wide range of other strategies are produced: strategies for children; for people with disabilities; for older people; for Roma; for deinstitutionalisation and so on, which often have priorities and timelines which are different from the overarching documents they are meant to relate to. Strategies, akin to the five-year plans of socialist planning, are meant to result in annual action plans, annual progress reports, and such like. In reality, even strategies for several years are not passed until after the period in question has begun and action plans and progress reports inevitably slip, also. Crucially, however, they form the substance around which diverse actors with diverse 'projects' can operate to compound fictions further. It is to these that we now turn.

\section{Flexible Agencification}

Combining a notion of 'flexibility' with that of 'agency' and 'agencification' actually refers to a wide range of processes which, when analysed through a temporal lens, become even more complex but are central to understanding welfare reforms in Central and South Eastern Europe. Over-structural understandings of change, or the lack of it, in welfare arrangements, give too little weight to agency, whether the actions of particular individuals or networks, or new institutions or 'agencies' created in a supposed attempt to 'speed up' reforms. Such actors and agencies are always themselves a product of complex power relations, of course, but also come to occupy and transform the very 'spaces of power' which allowed them to emerge initially (cf. Newman, 2012). 'Flex actors' or 'flex nets' (Wedel, 2011; Stubbs and Wedel, 2015) have a chameleon-like character, occupying blurred roles, sometimes contemporaneously, across a range of sites and settings. The contemporaneity or simultaneity of an actor who may be both plausibly local and international, with 
her own NGO whilst also working at a university and seconded as a Government policy advisor, or the agency which is plausibly both state and non-state, or a hybrid of both, should not distract us from the heterotemporalities of their existence. Implicated in "institutional fusions of power" (Wedel, 2011: 40) these flex actors position themselves to maximise opportunities, whether material, ideological, or both, consequent upon their occupancy of multiple roles. The emphasis, during and after the wars in Croatia and Bosnia-Herzegovina, on large numbers suffering from 'post-traumatic stress syndrome' opened a space for international and local advocates of 'psycho-social support', enrolled contemporaneously or sequentially to research the topic and present guestimates of the numbers affected, to advise donor and Governmental agencies on programming, to implement programmes within their 'own' NGOs or other hybrid implementing agencies, and even to evaluate the same programmes (Stubbs, 2005).

The creation of agencies to 'speed up' reforms is a common occurrence across post-communist Eastern Europe. In complex and contested state formations such as Bosnia-Herzegovina, where the central state has limited powers compared to those of the entities and indeed, in the Federation of B-H, the cantons or regions, the meanings and positionalities of such agencies can, also, be chameleon-like, artificially boosted by donor funds to assume powers which, in relation to dominant political structures, they do not possess. Even in supposedly more 'stable' structures, such agencies can reinforce a kind of 'welfare parallelism' (Stubbs and Zrinščak, 2009) advocating reforms which remained as convenient fictions or faced opposition from civil servants reacting against the favourable conditions and often higher salaries, which those working in such agencies received. Sometimes, formally state bodies are referred to by those "in the know' as "more like an NGO", such as the 'Social Inclusion and Poverty Reduction Unit' of the Government of Serbia (Stubbs and Zrinščak, 2019). In other cases, bodies which are formally NGOs take on tasks which appear to fit more within state structures, such as the work of IBHI in Bosnia-Herzegovina (cf. Stubbs, 2015a). Indeed, changing its name from the Independent Bureau for Humanitarian Issues to the Initiative for More Humane and Better Inclusion indicates a flexibility to even adapt nomenclature as well as position to fit 'new times'. Establishing a Social Innovation Fund in B-H within this NGO hybrid IBHI is, itself, a product of policy learning from the Serbian example of a 'transitional' state agency, the Social Inclusion and Poverty Reduction Unit (SIPRU) discussed above, staffed by persons from both the NGO and university world which attracted significant funding from international actors keen to 'speed up' reforms.

The EU's Structural Funds have further promoted the process of flexible agencification through the creation of multiple flexi-institutions. In Hungary, such agencies were built up in the early 2000s, as a 'signal' that 'reforms' were being 'prioritised' and 'fast-tracked' only for these agencies to subsequently be abolished, demolished, closed or reallocated in a very short period of time. In Hungary, the previously powerful regional funding agencies created to coordinate the initial wave of Structural Funds have now disappeared and have been replaced by completely centralised Ministerial agencies. Prominent new buildings with the EU flag flying, 
signalling the 'regional', have become empty; the flags, the curtains, and the people working there long gone or repurposed, with all traces of their past erased.

\section{Projectization}

One of the defining characteristics of 'projects' is their temporality: they have starting times and ending times even when, as frequently occurs, these are extended into the future, the future remains finite, not infinite. Across the region, in different ways in different conjunctures, we can note four broad waves of projectization, again marked by heterotemporalities with considerable overlap between the waves and no clear-cut moment in time when one wave ended and another began.

The first wave can be termed 'stand-alone projects' reflecting the possibilities for free floating initiatives in unstable environments within a 'crowded playing field' (Arandarenko and Golicin, 2007) of, largely, international, donors and an even larger pool of potential project implementors. Enabled by the lack of 'thick' structures of state regulation, these projects stand out for their sheer arbitrary diversity, relatively short-term time scales, and quick shifts from one 'target group' to another. They operated very much in the discursive space between the so-called 'developed' and the 'developing world' - never clearly identifiable as either only a 'social welfare project' or a 'social development project' - and contributed to what might be seen as typical semi-peripheral heterotemporalities: a rapidity of effort, an amassing of 'activities', but with little structural impact. In a sense, the core lasting impact of such 'stand-alone' projects may have been the creation of what Catherine Baker (2014) has termed a 'projectariat', prefiguring the emergence of short-term contracts and 'new' forms of flexible, read unstable, employment. Innovative microlevel 'spatial-temporal' fixes were also institutionalised when, as part of the 'exit strategy' of international organisations, they would 'leave behind' local 'successor organisations', themselves complex assemblages in translation with an interest in long-term survival. Such organisations tended to have more of an eye for the next project or projects rather than a focus on the current ones, quickly regressing from being what Duffield (2004) termed 'multi-mandated' to having no recognisable mandate at all other than their own organisational survival and the personal material gain of their founders.

The second wave refers to the fashion for so-called 'pilot' or 'demonstration' projects, notwithstanding the critique that this was often merely a label meant to disguise the randomness and arbitrariness of 'stand-alone' projects; "we have many pilots but no aeroplane", in the words of one of our respondents from a workshop in Bosnia-Herzegovina. At least referentially, then, 'pilots' were meant to have the potential to be 'scaled up', referring to their spatial dimension, and to become 'sustainable' or, indeed, a permanent feature of the welfare landscape, referring to their temporal feature. However superficially, then, 'pilots' were meant to derive from an initial assessment of the gaps, challenges or failings of existing social welfare. In the later stages, not least through a reform 'template' developed across the region and funded by the UK Government (Maglajlić Holiček and Rašidagić, 
2007), a key emphasis was on piloting new welfare mixes though local 'partnerships' between NGOs and state Centres for Social Work, without addressing, of course, the different temporal horizons of the diverse actors meant to become 'partners'. Often, instrumentalised sustainability failed to turn into real sustainability with some 'pilots', notably, instead of being integrated into welfare structures, existing as parallel services. Again, the temporalities of partnership and sustainability are complex, not least since, 'when push came to shove' towards the end of a 'project', staff who knew 'time was running out' had to negotiate with domestic policy makers who had 'time on their side', as was the case in a Norwegian child care initiative in the B-H city of Zenica (Stubbs, 2015a).

The third wave can be termed 'strategic support projects' in which complex arrangements are made to support strategic planning processes, including legislation and, which, inevitably, both bring 'projects' closer to the milieu of policy making whilst also distancing them from the centre through chains of subcontracting involving consultancy contracts and consortia of diverse 'providers'. These diverse spatialities, in a sense heterospatialities, are matched by heterotemporalities with consultants whose inputs are measured in days working with, or at least alongside, civil servants on permanent contracts.

In the fourth wave, with EU Structural funds, the 'project' becomes installed in frontline Ministries, as noted above in the case of Hungary in relation to 'flexible agencification'. This does not always have integrating effects, however, since a range of actors, including consortia of external consultants, continue to be involved. In addition, specific Departments are often created within Ministries staffed by those with an ambition, through their project work, to work eventually within the European Union. Again, a disconnect of temporalities can occur with 'business as usual' and 'projects' having little linkage to one another and operating, again, according to different temporal modalities.

As noted above, Hungarian welfare reforms have also long been associated with 'projects'. Projectisation has been widely promoted by actors such as the World Bank, the IMF and the EU. A World Bank project beginning in 1998, which has resulted in the effective privatisation of pension funds, was presented as 'neat', 'quick' and 'radical'. The heterotemporality of this project is more interesting, however: it had a lifespan of 12 years, and in 2010 the Hungarian government renationalised the pension system and transferred second pillar payments into the national budget. The lifespan of 'quick' projects and particularly their social consequences are long-term, of course: in this case, the pension system's future sustainability has become very fragile. The 'quick' has become 'enduring'. The tenses are traded, merged or collapsed. EU Structural Funds have also introduced a key feature into post-communist welfare' by projectizing 'social innovation' and spatialised, regionalised, social policy thinking. On the one hand, the projectization induced by Structural Funds in Hungary exists on the margins of policy; a series of small 'projects' are implemented in remote villages, ticking boxes for social causes promoted by the EU such as Roma integration, while being deeply unpopular with the right-wing government. Structural funds also represent a very small part of 
overall social spending. On the other hand, these ongoing projects are very handy for the current Hungarian government that does not wish to spend on and promote social policy. Ironically, the 'social investment' of the Structural Funds in a sense allows for a 'social divestment' strategy by the government (Stubbs and Lendvai-Bainton, 2020). While the Structural Funds promote educational inclusion, language support and student exchange, the government is legislating Roma segregation, withdrawing significant funding from core educational activities, and introducing populist and nationalist new curricula. Similarly, Structural Funds are used to promote the inclusion of disabled people whilst a systematic and large-scale reinstitutionalisation is taking place in a segregated manner. While new child care facilities are being built with Structural Funds, these institutions can only survive financially long-term if they are successful in applying for continued funding to the EU. Core funding has been drastically reduced across the board, in education, social care and social assistance. Projectization allows for 'social divestment' (Lendvai and Stubbs, 2015).

\section{Unsettling Time in Unsettled Times}

To conclude, four issues seem to us to be worthy of more discussion in order to reinstall the study of temporalities within critical policy studies. A conceptual vocabulary of heterotemporality, temporal rhythms and disjunctures requires us to move away from the methodological dominance of historical institutionalist analysis in mainstream social policy research and to rely much more on the rich 'micro-political' understandings derived from more sensitive ethnographic studies. Crucially, there is also a need for ethnographic 'studying through' to connect a range of actors in the policy process neither neglecting, nor privileging, some over others. Within our own work, the relative neglect of service users and front-line service practitioners, problematic in many ways, is amplified when temporalities are in focus. Others at the forefront of a new wave of ethnographic and anthropological work on social welfare in the region have demonstrated the impacts of uneven, hybrid, unpredictable, residualised, and increasingly punitive forms of welfare on service users.

Azra Hromadžić (2015), for example, has described the 'semi-absence' of both the family and the state in the context of post-war and post-socialist reconfigurations in Bosnia-Herzegovina, inducing a crisis of care in which mere survival and the reproduction of the self and the management of intimate relationships of kin is a seemingly constant, never ending, struggle. Likewise, in her study of mothers of children with disability, Čarna Brković (2017) argues that "the ambiguous ground of social protection", experienced as "erratic, unpredictable and mysterious", requires extreme flexibility, to mobilize whatever resources possible, including any possible informal contacts, just to get a fraction of the services needed. Welfare users in both studies invoke a seemingly lost logic of welfare as a right and a duty of the state in the face of the realities of a system which is limited, discretionary and largely lacking in compassion. Survival depends on a constant struggle to find and gain access to the right people who, with enough luck, when "all the pieces fall into place", might support 'humanitarian actions' allowing you to get by, at least for a while. 
In a sense, these analyses complement our own work on the temporal and spatial instability of emerging assemblages of welfare and care. Diverse modalities and practices of care appear to co-exist which are "fraught, uncertain and provisional", creating new chains of meaning, new hierarchies of power and agency, new forms of inclusion and exclusion, new regimes of blame and of virtue, recalibrations of what Andrea Muehlebach (2012) has termed 'moral citizenship', and new marginalisations, subordinations and silences (cf. Stubbs, 2016). The heterotemporalities of policy are clear from the reactions of Governments to the COVID-19 pandemic with 'lockdowns' simultaneously producing a sense that time has 'stood still', 'slowed down' and 'speeded up', eroding distinctions between 'work' and 'non-work' time (Stubbs, 2020).

Secondly, more attention needs to be paid to the temporalities of what we have termed 'variegated austerity capitalisms' (Lendvai and Stubbs, 2015). Unsurprisingly, concepts derived from critical geography appear more suited to addressing the 'spatial' compared to the temporal dimensions of processes of variegation. Nevertheless, some ways of understanding 'variegated temporalities' as also relational and structural is needed. Some hints at what this might entail can be found, perhaps, in understandings of 'layered welfare' and in work which explores the heterotemporalities of people living on a low income struggles for survival in the context of the temporal disciplinarities of welfare agencies (Daly and Kelly, 2015). Again, the pandemic policy response has shown how essential and non-essential work becomes both rigidly divided and intimately connected, as temporalities are both stretched and shrunk (Stubbs, 2020), reproducing and transforming hierarchies of value and worth.

Thirdly, there is a need to be extremely cautious about the concept of the 'semi-periphery'. Although Blagojević's formulation is an immense improvement on its 'frozen' conceptualisation within world systems theory, there is a danger that the concept of the semi-periphery can itself, unintentionally, reproduce a kind of orientalism which is complicit in the Othering of the region, at the same time contrasting this with an uncritical view of the 'core' or 'the West' as if the confluences of neo-liberalism, repatriarchalisation, new moral conservatism, clientelistic capture and authoritarian nationalisms cannot be found there. This is why it is the variegated nature of the processes, and the relations between core and semiperiphery, as well as the periphery, which are important. The use of the concept must be more in decentering an imagined West (or a newly imagined North), and a search for both a careful calibration of connections and documentation of differences and discontinuities. Indeed, a methodology of 'following the policy' advocated by Peck and Theodore which we would translate as 'follow the modalities and discourses of policy translation' could well uncover a number of unexpected connections. One respondent working for an international NGO in Bosnia-Herzegovina expressed his surprise to one of us to find, on returning to the UK, that many elements of what we had termed 'projectization' and 'flexible agencification' were now recognizable to him in community work approaches in inner London boroughs. Indeed, it may be no coincidence that Janine Wedel is now able to use concepts around 'flex actors' 
developed in her work in early transition Poland, to understand developments in the contemporary United States (Wedel, 2011). Processes which resemble semiperipheralisation, marked by an interstitial sense of being 'between the developed and the underdeveloped world' can, then, have unexpected and multiple directionalities and are marked, again, by complex heterotemporalities.

Fourthly, the relationship between heterotemporalities and power also needs further scrutiny. The concept of heterotemporalities does not imply a flattened conception of power; indeed, quite the opposite. We would argue that power is always in operation and that 'temporal logics' (Ringel, 2016) enable, privilege and foreground certain kinds of policy worlds over and above others. Time in a pandemic, framed in terms of 'waves' and 'changing responses as we know more' is illustrative of this. It is the temporal structuring of language, imaginaries, institutions and practices, delineating the limits of possibility, that reproduces and reinforces power relations. Heterotemporalities are also deeply structured by power when one looks at EU integration, accession and processes of Europeanisation. The temporalities of EU Accession have erased politics from managing, formulating and contesting social relations in the 'candidate', 'associate', 'aspiring' countries and has led to a depoliticisation of democratic politics in the name of democratisation. New forms of coercive governance, introduced by the EU following the economic crisis post2008, operate with tighter and tighter debt management targets and narrower timeframes for compliance. 'Pandemic times' have resulted in a mixture of authoritarian, regulatory and libertarian exceptionalism (Stubbs, 2020) as 'health' and 'the economy' are weighed against each other. However, as much of post-colonial studies reminds us, 'talking back' and post-colonial 'unlearning', challenging 'neo-colonial' spatialities and temporalities, also inform, morph and deflect power relations in unexpected ways.

\section{References}

Allen, T. 2008. A Republic in Time: temporality and social imagination in NineteenthCentury America. Chapel Hill: University of North Carolina Press.

Arandarenko, M. and P. Golicin. 2007. 'Serbia'. In: B. Deacon and P. Stubbs (eds.) Social Policy and International Interventions in South East Europe. Cheltenham: Edward Elgar, pp. 167-186.

Arsenijević, D. and S. Wastell. 2017. 'The Enduring Transition', Paper for workshop Translating Policy in the Semi-Periphery. Regensberg: GSOSES.

Avery, G. 2009. 'Uses of Time in the EU's Enlargement Process'. In: Journal of European Public Policy, 16(2): 256-269.

Bakhtin, M. 1981. The Dialogic Imagination: four essays. Austin: University of Texas Press.

Baker, C. 2014. 'The Local Workforce of International Intervention in the Yugoslav Successor States: 'precariat' or 'projectariat'? Towards an agenda for future research', International Peacekeeping, 21(1): 91-106. 
Bako, T. G. Cseres, J. Kalman, G. Molnar and T. Szabo. 2014. 'A munkaeropiac peremen levok es a koltsegvetes' (The budget and people on the edge of the labour market). Budapest: MTA Kozigazgatasi Intezet.

Blagojević, M. 2009. Knowledge Production at the Semi-Periphery: a gender perspective. Belgrade: Institute for Criminological and Sociological Research.

Brković, C. 2017. Managing Ambiguity: how clientelism, citizenship and power shape personhood in Bosnia and Herzegovina. New York: Berghahn books.

Buchs, M. 2008. 'The Open Method of Co-Ordination as a 'Two-level Game”, In: Policy \& Politics, 36)1): 21-37.

Clarke, J. 2004. Changing Welfare, Changing States: new directions in social policy. London: Sage.

Clarke, J. 2010. 'Of Crises and Conjunctures: the problem of the present'. In: Journal of Communication Inquiry, 34(4): 337-354.

Clarke, J. D. Bainton, N. Lendvai and P. Stubbs. 2015. Making Policy Move: towards a politics of translation and assemblage. Bristol: Policy Press.

Coffey, A. 2004. Reconceptualizing Social Policy: sociological perspectives on contemporary social policy. Maidenhead: Open University Press.

Dagnino, E. 2007. 'Citizenship: a perverse confluence'. In: Development in Practice, 17(4/5): 549-556.

Daly, M. and G. Kelly. 2015. Families and Poverty: everyday life on a low income. Bristol: Policy Press.

De la Porte, C. 2011. 'Principal-agent theory and the Open Method of Co-ordination: the case of the European Employment Strategy’. In: Journal of European Public Policy, 18(4): 485-503.

Domazet, M. and D. Marinović Jerolimac. 2014. 'Sustainability on the semi-periphery: an impossible topic in a non-existent place?'. In: M. Domazet and D. Marinović Jerolimac (eds.), Sustainability Perspectives from the European Semi-periphery. Zagreb: Heinrich Boell stiftung, pp. 19-49.

Duffield, M. 2004. 'Carry On Killing: global governance, humanitarianism and terror'. DIIIS Working Paper 2004/3, Copenhagen: Danish Institute for International Studies, https://www.files.ethz.ch/isn/18761/carry_on_killing.pdf

European Commission Communication - Establishing a European Pillar of Social Rights. COM (2017) 250 final, 26 April, https://eur-lex.europa.eu/legal-content/EN/TXT/ $\mathrm{PDF} /$ ?uri $=$ CELEX:52017DC0250\& from $=\mathrm{EN}$

Fabian, J. 1983. Time and its Other: how anthropology makes its object. New York: Columbia University Press.

Filippini, M. 2016). Using Gramsci: a new approach. London: Pluto.

Gilbert, A. 2013. 'Beyond Nostalgia: other historical emotions'. In: History and Anthropology, 30(3): 293-312

Goetz, K. 2006. 'Territory, Temporality and Clustered Europeanization'. In: Political Science Series, 109. Vienna: Institute for Advanced Studies.

Gordy, E. 2013. Guilt, Responsibility and Denial: the past at stake in post-Milošević Serbia. Pennsylvania: University of Pennsylvania Press. 
Gould, J. 2004. 'Positionality and Scale: methodological issues in the ethnography of aid'. In: J. Gould and H. Secher Marcussen (eds.) Ethnographies of Aid: exploring development texts and encounters, IDS. Roskilde: Occasional Paper, 263-290.

Government of Croatia (2010) Conference Memorandum, JIM-JAP, 11 February, https://mdomsp.gov.hr/userdocsimages/arhiva/files/40895/CONFERENCE_ MEMORANDUM.pdf

Halberstam, J. 2005. In a Queer Time and Place: transgendered bodies, subcultural lives. New York: University Press.

Hoffman, D. et al. 2017. Croatia's Captured Places: research report-case studies on the quality of local governance in Croatia. Zagreb: GONG, https://www.gong.hr/media/ uploads/croatia $\% 27$ s_captured_places.pdf

Hromadzic, A. 2015. "Where were they until now?" Aging, care and abandonment in a Bosnian town. In: Etnološka tribina 38: 3-29.

Huebener, P. S. O’Brien, T. Porter et al. 2016. 'Exploring the Intersection of Time and Globalization'. In: Globalizations, 13(3): 243-255.

Jansen, S., Č. Brković and V. Čelebičić. 2016. 'Introduction: new ethnographic perspectives on mature Dayton Bosnia and Herzegovina'. In: S. Jansen et al. (eds.) Negotiating Social Relations in Bosnia and Herzegovina: semiperipheral entanglements. London: Routledge, 1-28.

Jansen, S. 2017. 'Bordering Bosnia and Herzegovina: translation, assemblage and hierarchy in the European semi-periphery'. In: Paper for workshop, Translating Policy in the Semi-Periphery. Regensberg: GSOSES.

Jessop, B. (n.d.) 'The roles of theory and meta-theory in studying socio-economic development models', Demologos: http://demologos.ncl.ac.uk/conference/session2.pdf.

Jessop, B. 2004. 'Spatial Fixes, Temporal Fixes, and Spatio-Temporal Fixes'. Lancaster University: Department of Sociology, https:/www.lancaster.ac.uk/fass/resources/ sociology-online-papers/papers/jessop-spatio-temporal-fixes.pdf

Juhasz, B. 2012. 'Orban's Politics: a gender perspective'. Budapest: Friedrich Ebert stiftung, Working Paper.

Klein, M. 2007. The Shock Doctrine: the rise of disaster capitalism. New York: Metropolitan Books.

Lendvai, N. 2007. 'Europeanization of social policy? Prospects and challenges for South East Europe'. In: B. Deacon and P. Stubbs (eds.) Social Policy and International Interventions in South East Europe. Cheltenham: Edward Elgar, pp. 22-44.

Lendvai, N. 2015. 'Soft Governance, Policy Fictions and Translation Zones: European policy spaces and their making'. In: J. Clarke et al. Making Policy Move: towards a politics of assemblage and translation. Bristol: Policy Press, pp. 131-156.

Lendvai-Bainton, N. 2017. 'Radical Politics in Post-Crisis Hungary: illiberal democracy, neoliberalism and the end of the welfare state'. In: P. Kennett and N. LendvaiBainton (eds.), Handbook of European Social Policy. Cheltenham: Edward Elgar, pp. $400-415$.

Lendvai, N. and D. Bainton 2013. 'Translation: towards a critical comparative social policy agenda'. In: P. Kennett (ed.) A Handbook of Comparative Social Policy, Second edition. Cheltenham: Edward Elgar, pp. 115-136. 
Lendvai, N. and P. Stubbs. 2007. 'Policies as Translation: situating transnational social policies'. In: S. Hodgson and Z. Irving (eds.) Policy Reconsidered: meanings, politics and practices. Bristol: Policy Press, pp. 173-190.

Lendvai, N. and P. Stubbs. 2009. 'Assemblages, Translation and Intermediaries in South East Europe: rethinking transnationalism and social policy. In: European Societies, 11(5): 673-695.

Lendvai, N. and P. Stubbs. 2015. 'Europeanization, Welfare and Variegated Austerity Capitalisms - Hungary and Croatia'. In: Social Policy and Administration, 49(4): 445-465.

Maglajlić Holiček R. A. and E. K. Rašidagić. 2007. 'Bosnia and Herzegovina'. In: B. Deacon and P. Stubbs (eds.) Social Policy and International Interventions in South East Europe. Cheltenham: Edward Elgar, pp. 149-166.

Marcus, G.1995. 'Ethnography In/Of the World System: the emergence of multi-sited ethnography'. In: Annual Review of Anthropology, 24: 95-117.

Martinelli, F. and A. Novy (n.d.) 'A Methodology for Empirical Research on Spatial Socio-Economic Development', Demologos, http://demologos.ncl.ac.uk/conference/ session3.pdf

Mizielinska, J. and R. Kulpa 2011. 'Contemporary Peripheries': Queer studies, circulation of knowledge and East/West divide'. In: R. Kulpa and J. Mizielinska (eds.) DeCentering Western Sexualities: Central and Eastern European Perspectives. Farnham: Ashgate, pp. 11-26.

Muehlebach, A. 2012. The Moral Neoliberal: welfare and citizenship in Italy. Chicago: University Press.

Newman, J. 2012. Working the Spaces of Power: activism, neoliberalism and gendered labour. London: Bloomsbury.

Peck, J. 2011. 'Geographies of Policy: from transfer-diffusion to mobility-mutation'. In: Progress in Human Geography, 35(6): 773-797.

Peck, J. and N. Theodore. 2015. Fast Policy: experimental statecraft at the thresholds of neoliberalism. Minneapolis: University of Minnesota Press.

Pratt, M-L. 1992. Imperial Eyes: travel writing and transculturation. Abingdon: Taylor \& Francis.

Ringel, F. 2016. 'Beyond Temporality: notes on the anthropology of time from a shrinking fieldsite'. In: Anthropological Theory, 16(4): 390-412.

Ruggie, J. 1998. Constructing the World Polity: essays on international institutionalism. London: Routledge.

Sassen, S. 2000. Cities in a World Economy, Fifth edition. London: Sage.

Shore, C. and S. Wright (eds.) 1997. Anthropology of Policy: perspectives on governance and power. London: Routledge.

Sissenich, B. 2007. Building States Without Society. Rowman and Littlefield: Lanham.

Stoker, G. 2006. Explaining political disenchantment. In: The Political Quarterly, 77(2): 184-194.

Stubbs, P. 2001. 'Social sector' or the diminution of social policy? Regulating welfare regimes in contemporary Bosnia-Herzegovina'. In: Ž. Papić (ed.) Policies of 
International Support to South Eastern European Countries: lessons (not) learnt from BiH. Sarajevo: Muller, pp. 95-107. https://www.esiweb.org/pdf/bridges/bosnia/ Stubbs_ChVIII.pdf

Stubbs, P. 2005. 'Transforming Local and Global Discourses: reassessing the PTSD movement in Bosnia and Croatia'. In: D. Ingleby (ed.) Forced Migration and Mental Health: rethinking the care of refugees and displaced persons. New York: Springer, pp. 53-66.

Stubbs, P. 2013. 'Flex actors and philanthropy in (post-)conflict arenas: Soros' Open Society Foundations in the post-Yugoslav space'. In: Politicka misao, 50(5): 114138.

Stubbs, P. 2015a. 'Performing Reform in South East Europe: consultancy, translation and flexible agency'. In Clarke, J. et al. Making Policy Move: towards a politics of translation and assemblage. Bristol: Policy Press, pp. 65-94.

Stubbs, P. 2015b. 'Translating Welfare Assemblages in the 'New' Eastern Europe: redomaining the social?'. In: E-J. Lee and H. Mossler (eds) Lost and Found in Translation. Frankfurt am Main: Petar Lang, pp. 31-54.

Stubbs, P. 2016. 'Resistance in Austerity Times: social policy, social work and social movements in crisis conditions'. In: Dialogue in Praxis, 5(1): 23-29. http:// dialogueinpraxis.net/index.php? $\mathrm{id}=5 \& \mathrm{a}=$ article $\&$ aid $=58$

Stubbs, P. 2018. 'Slow, Slow, Quick, Quick, Slow: power, expertise and the hegemonic temporalities of austerity'. In: Innovation, 31(1): 25-39.

Stubbs, P. 2020. 'Where does the time go? Time and temporality in a pandemic'. H-ALTER, 16 September, https://www.h-alter.org/vijesti/where-does-the-time-go-time-andtemporality-in-a-pandemic

Stubbs, P. and N. Lendvai. 2016. 'Re-assembling and Disciplining Social Europe: turbulent moments and fragile f(r)ictions'. In: Z. Krajina and N. Blanusa (eds.) EU, Europe Unfinished: mediating Europe and the Balkans in a time of crisis. London: Rowman \& Littlefield, pp. 31-56.

Stubbs, P. and N. Lendvai-Bainton. 2020. 'Authoritarian Neoliberalism, Radical Conservatism and Social Policy Within the European Union: Croatia, Hungary and Poland. In: Development and Change, 51(2): 540-560.

Stubbs, P. and J. Wedel. 2015. 'Policy Flexians in the Global Order'. In: A. Kaasch and K. Martens (eds.) Actors and Agency in Global Social Governance. Oxford: University Press, pp. 214-232.

Stubbs, P. and S. Zrinščak. 2009. 'Croatian Social Policy: the legacies of war, state-building and late Europeanization'. In: Social Policy \& Administration, 43(2): 121-135.

Stubbs, P. and S. Zrinščak. 2013. 'Social Policy and Croatia's EU Membership: Glass half full or half empty'. Zagreb: Heinrich Boell stiftung. https://www.scribd.com/ document/150586283/Stubbs-Zrinscak-Social-Policy-and-Croatia-s-EU-Membership

Szikra, D. 2014. 'Democracy and welfare in hard times: The social policy of the Orbán Government in Hungary between 2010 and 2014'. In: Journal of European Social Policy, (11), pp. 1-15.

Wedel, J. 2001. Collision and Collusion: the strange case of Western aid to Eastern Europe. New York: St. Martin's Press. 
Wedel, J. 2004. ' Studying through' a globalizing world: building method through aidnographies'. In: J. Gould and H. Secher Marcussen (eds.) Ethnographies of Aid: exploring development texts and encounters. Roskilde: University Centre, Occasional Paper, 24: 149-173.

Wedel, J. 2011. Shadow Elite: how the world's new power brokers undermine democracy, government, and the free market. New York: Basic Books.

Williams, R. 1977. Marxism and Literature. Oxford: University Press.

Xin Lui, C. 2012. 'Theorising Social Time: uneven and combined development as a Historical-Materialist international theory'. Paper presented to Millennium Annual Conference, London.

https://millenniumjournal.files.wordpress.com/2012/10/liu-paper-submitted-to-lsemillennium-annual-conference.pdf.

Zeitlin, J. 2005. 'Social Europe and Experimentalist Governance: towards a new constitutional compromise?'. European Governance paper (EUROGOV) C-05-04.

http://www.mzes.uni-mannheim.de/projekte/typo3/site/fileadmin/wp/pdf/egpconnex-C-05-04.pdf

Županov, J. 2002. Od komunističkog pakla do divljeg kapitalizma. Zagreb: Hrvatska sveučilišna naklada.

Ноеми Лендваи Бејнтон

Пол Стабс

\section{ТЕМПОРАЛНОСТИ ПРЕВОЪЕЬА ПОЛИТИКА НА ПОЛУПЕРИФЕРИЈИ: ПОНОВНИ ПРЕГЛЕД ЕВРОПЕИЗАЦИЈЕ РЕФОРМИ ДРЖАВЕ БЛАГОСТАҢА У ЦЕНТРАЛНОЈ И ЈУГОИСТОЧНОЈ ЕВРОПИ}

Ancтракт: Овај чланак има за циљ концептуализацију времена и темпоралности у контексту полупериферних друштвених односа, са посебним фокусом на транснационалне димензије превођења политика. Посебно показујемо како, чак и унутар коегзистенције вишеструких темпоралности, „време политика” и „време у политикама” омогућавају или фаворизују одређене типове процеса социјалних мера у односу на друге. Враћање на бројне теме из нашег етнографског рада о нерешеним реформама социјалних политика, доминантно из постјугословенског и мађарског контекста и везујући се доминантно на такозвани процес европеизације, омогућило нам је да ставимо у први план просторно-временске димензије процеса социјалних мера. У раду се истражују неки од кључних изазова питања како третирати време у оквиру критичких студија политика.

Кључне речи: темпоралности, превођење политика, критичке студије политика, полупериферија, европеизација 